\title{
Planken som forsvann. Ein analyse av avgangsprøva i norsk gjennom 50 år
}

Tidsskriftet Sakprosa

Bind 10, Nummer 2

(C) 2018

10.5617/sakprosa.5971

A. Løvland

$1 / 36$

Sakprosa.no 


\section{Sammendrag}

Alle elevar i den norske grunnskulen kan bli trekte ut til å gjennomføre avgangsprøva i norsk. I læreplanane legg ein vekt på at elevane skal få opplæring ut frå eigne føresetnader, og det er derfor interessant å undersøke korleis dette kjem til uttrykk i avgangsprøvene. Materialet er avgangsprøvene frå 1967 til 2017. Lesing og skriving har stått sentralt i heile perioden, men faget har også ein eigen kunnskapskomponent som elevane blir prøvde $i$. Materialet er omfattande og variert, men eg har likevel sett trekk som gjer det mogeleg å peike på tre karakteristiske evalueringspraksisar som til dels følger etter kvarandre i tid: Tilpassa regulering er kjenneteikna av at skulen tek ansvaret for at den enkelte blir presentert for passande oppgåver. Tilrettelagd valfridom er kjenneteikna av at elevane făr valfridom til sjølv å finne passande oppgåver. Krevjande likebehandling er ein praksis der ein legg lista like høgt for alle gjennom å snevre inn valfridomen. Hovudkonklusjonen er at interessa for å gje også svake elevar ei mogelegheit til å lukkast ut frå sine føresetnader har blitt mindre over tid.

\section{Abstract}

All students in the Norwegian elementary school can be selected to complete the final exam in Norwegian. The curriculum emphasizes that students will receive training based on their own prerequisites and it is therefore interesting to investigate how this will be taken into account in the pass tests. The material is the final tests from 1967 to 2017 - fifty sets of tests. Reading and writing have been central throughout the period, but the subject also has its own knowledge component in which the students are tried. The material is extensive and varied, but I have nevertheless seen features that may make it possible to look at three distinctive phases in the evaluation practice: Adapted regulation is characterized by the fact that the school takes responsibility for the individual being presented for suitable tasks. Facilitated freedom of choice
A. Løvland 
is characterized by the fact that the pupils are given freedom of choice to find suitable assignments for themselves. Demanding equal treatment is a practice where one sets the same requirements for all through narrowing down freedom of choice. The main conclusion is that the interest for giving weak students an opportunity to succeed based on their prerequisites has become weaker over time.

Nøkkelord: Avgangsprøve, norskfaget, lesing, skriving, vurdering, eksamen, norskeksamen, tilpassa opplæring, multimodalitet, skole.

\section{Om forfatteren:}

Anne Løvland er professor ved Institutt for nordisk og mediefag, Universitet i Agder. 


\section{Planken som forsvann.}

\section{Ein analyse av avgangsprøva i norsk gjennom 50 år}

Eksamensordninga i grunnskulen er noko som gjeld oss alle. I ein kommentar i Aftenposten 7. mai i år etterlyser journalist Helene Skjeggestad ei endring av eksamenssystemet for norsk grunnskule. Ho meiner det er oppsiktsvekkande at skulen blir fornya utan at det skjer ei tilsvarande endring i eksamenssystemet. I tittelen les vi at «[e]ksamensordningen er gammeldags og utdatert». Skjeggestad er mest oppteken av at eksamensførebuing kanskje ikkje er så nyttig, og at elevane kanskje ikkje blir så motiverte av tanken på eksamen. Samtidig skriv ho «med glimt i øyet og et snev av alvor: Det gjør litt godt å vite at hvis vi måtte lide, skal også dagens ungdom få føle på nervøsiteten. Kjenne på følelsen av aldri å være godt nok forberedt og frykten for at noen timer skal sende livet i en annen retning enn man ønsker». Her er mange ting å gripe fatt i. Det mest grunnleggande: Er det slik at til dømes avgangsprøva i norsk ikkje har endra seg i «manns minne»? Når ein tek innover seg at slike prøver «kan sende livet i en annen retning enn man ønsker», er det opplagt av samfunnsmessig interesse å reflektere over korleis evalueringsordninga verkar.

Elevane som var seksten år i 1967, og som nærmar seg pensjonsalder nå, har vore med på ei rivande samfunnsutvikling på mange felt. Den teknologiske utviklinga, som kanskje er det tydelegaste utviklingstrekket, har også ført til ei sterk endring av tekstkulturen. Nye sjangrar har utvikla seg, og gamle har blitt borte. Der vi før bruka tid på å skrive sirlege private brev, sender vi nå raske tilstandsrapportar på sosiale medium. Trass i denne tekstlege utviklinga framstår eksamen i norsk hovudmål uendra i den forstand at norske sekstenåringar kvar vår i femti år har bruka ein av dei siste obligatoriske skuledagane i livet på å svare på desse oppgåvene som blir spesiallaga for dei. Slik sett er
A. Løvland 
også femti årgangar av årsprøva i norsk hovudmål eit godt utgangspunkt for å analysere kontinuitet og endring i norskfaget. ${ }^{1}$

Sjølv om tekstkulturen har gjennomgått ei sterk utvikling, veit vi at elevane både før og nå har ulike kompetansenivå. Problemstillinga for artikkelen tek utgangspunkt i at avgangsprøvene skal fortelje både svake og sterke elevar noko om «kva retning livet kan ta». I eit samfunn der vi har tradisjon for å vere opptekne av at elevar med ulike føresetnader skal kunne lukkast, er eg altså interessert i å finne ut korleis forventingane om at elevane har ulike kompetansenivå, kjem til uttrykk i oppgåvesetta.

\section{Materialet, analysemåten og tidlegare forsking}

\section{Materiale}

Femti er eit rundt tal, men bakgrunnen for å undersøke oppgåver frå 1967 er at sist på sekstitalet kom ein for alvor i gang med avgangsprøve for niårig grunnskule i Noreg. Tidlegare hadde elevane bare gått sju år i obligatorisk folkeskule. Dei første åra var dette ei forsøksordning som så blei permanent frå 1969. I løpet av desse femti åra har seks ulike læreplanar vore gjeldande for den norske grunnskulen. Læreplan for forsøk med niårig grunnskole kom i 1960 (Forsøksrådet for skoleverket, 1960), medan norskplanen i

\footnotetext{
${ }^{1}$ Prøvene frå åra 1968-1999 er trykte i samlingar som er gjevne ut i årgangar på ulike forlag (Universitetsforlaget og Grøndahl \& Søn) eller som meir uformelle trykksaker. Det er Grunnskolerådets eksamenssekretariat som står bak desse samlingane. Det har ikkje alltid vore mogeleg å finne desse samlingane på Nasjonalbiblioteket. I ein del tilfelle har eg difor laga kopiar av prøvene frå Riksakivet. Prøve frå 1976 har ikkje vore mogeleg å skaffe. Utdanningsdirektoratet har gjeve meg papirbaserte og digitale kopiar av prøvene frå 2000 til 2017. Ein del av materialet i førebuingshefta har likevel ikkje vore tilgjengeleg for meg på grunn av spørsmål knytte til opphavsrett. Materialet gjev likevel eit representativt bilete som dannar eit godt grunnlag for konklusjonane mine.
}
A. Løvland
$5 / 36$
Sakprosa.no 
Kunnskapsløftet blei laga i 2006 og seinare revidert i 2008, 2010 og 2013 (Utdanningsdirektoratet, 2013). Mellom desse har vi hatt planar for norskfaget i Mønsterplan for grunnskolen frå 1974 (Kirke- og undervisningsdepartementet, 1974) og 1987 (Kirke- og undervisningsdepartementet, 1987) og i Læreplanverket for den 10-årige grunnskolen frå 1997 (Kirke-, undervisnings- og forskningsdepartementet, 1996).

Planane har ulik organisering og vektlegging, og tanken om at lærestoffet skal tilpassast elevar med ulike føresetnader, er ikkje like sterk gjennom heile perioden, men i den eldste og den nyaste planen finst det formuleringar som uttrykker dette målet på tilnærma same måte:

Ut fra sine individuelle forutsetninger skal elevene læres opp til å gi muntlig og skriftlig uttrykk for sine tanker, følelser, erfaringer og opplevelser (Forsøksrådet for skoleverket, 1960, s. 59).

Samtidig skal norskfaget utvikle elevenes språkkompetanse ut fra de evner og forutsetninger den enkelte har (Utdanningsdirektoratet, 2013).

I analysen av materialet vil eg undersøke korleis eksamensoppgåvene møter desse målsetjingane.

Det er ikkje bare planverket som har blitt endra gjennom desse åra; også eksamensformene har skifta. Det har likevel lege fast at eksamensordninga i norsk har hatt både ein skriftleg (hovud- og sidemål) og ein munnleg del, og at elevane kan trekkast ut til ingen, ein eller begge desse delane. Tradisjonelt har den skriftlege prøva vore ei lese- og skriveprøve, medan den munnlege prøva har lagt vekt på norskfagleg kunnskap. Det er ikkje mogeleg å lage ei fullstendig oversikt over alle endringar i eksamensforma fordi det blir gjort
A. Løvland
$6 / 36$
Sakprosa.no 
mindre endringar heile tida, men denne oversikta viser den tidsmessige plasseringa av nokre trekk eg kjem inn på seinare i samband med dei aktuelle læreplanane:

1960: Læreplan for forsøk med niårig grunnskole

○ 1969: Innføring av niårig grunnskole

1974: Mønsterplanen

- 1976 eller 1977: Siste plandelte avgangsprøve

- 1980: Siste avgangsprøve med det som i denne studien blir karakterisert som tilpassa sakprosa

- 1984: Siste eksamen med skriving av det som i denne studien blir karakterisert som funksjonell sakprosa

1987: Mønsterplanen

○ 1989: Første avgangsprøve med sjangerspørsmål

○ 1989: Innføring av inspirasjonstekstar

1997: Læreplan

○ 1997: Innføring av 10-årig grunnskule

○ 2000: Første avgangsprøve med separat teksthefte og førebuingstid

2006: Kunnskapsløftet

- 2006 og 2007: Elevane skal utforme eigne skriveprosjekt

○ 2008: Kombinert avgangsprøve i hovud- og sidemål

Tabell 1: Oversikt over læreplanane i perioden og viktige endringspunkt

A. Løvland 


\section{Analysemåte}

Målet er å vise korleis oppgåvene har endra seg, og kva verknad dette kan tenkast å ha fått for svake elevar. Eg vil sjølvsagt lese oppgåvene inn i konteksten av planar og eksamensformer, men målet med studien er ikkje å vise kvifor oppgåvene har endra seg. Analysemåten er altså ikkje tilpassa eit mål om å opplyse alle koplingar som opplagt finst mellom oppgåvetypar og endringar i planverk og eksamensform som har bakgrunn i fagleg nytenking.

I startfasen av arbeidet hadde eg også ei ganske open tilnærming til kva eg ville oppleve som interessant i oppgåvesetta. Dette har også påverka analysemåten. Eg har gått gjennom oppgåvesetta mange gonger og notert endringspunkt på mange ulike felt. Dei trekka eg har funne, har danna utgangspunktet for nærlesing ut ifrå det grunnleggande spørsmålet: Korleis ville ein fagleg svak elev hatt det med desse oppgåvene? Slik håpar eg å kunne peike på liner som kan lesast inn i ein større samanheng enn den fagdidaktiske. Eg har sjølvsagt ikkje eit materiale som kan «bevise» at svake elevar vil lide under ulike oppgåvetypar, men eg reiser spørsmålet.

\section{Tidlegare forsking}

Det er publisert fleire studiar av oppgåvene i avgangsprøva for grunnskulen som kvar for seg dekker delar av den perioden eg har teke føre meg. Andre forskarar, til dømes Egil Børre Johnsen, har studert eksamen for vidaregåande skule (Johnsen, 1997), men dei går eg ikkje inn på sidan problemstillinga er tett knytt til at dette er ei prøve som alle norske elevar kan trekkast ut til.

Forskingsprosjektet «KAL - Kvalitetssikring av læringsutbyttet i norsk skriftlig» er det mest omfattande prosjektet knytt til avgangsprøva. Bakgrunnen for prosjektet var Reform 97, som innebar ei omlegging til 10årig grunnskule og innføringa av L97 som læreplan. Prosjektet undersøkte
A. Løvland
$8 / 36$
Sakprosa.no 
læringsutbyttet hos elevane i norsk skriftleg gjennom eit representativt utval av elevsvar på avgangsprøva i norsk i åra 1998, 1999, 2000 og 2001. Det er altså oppgåvesvara frå elevane og den vurderinga sensorane gjorde av desse, som er det viktigaste studieobjektet, men Wenche Vagle og Lars Sigfred Evensen har som ein del av prosjektet også studert samanhengen mellom dei oppgåvetypane elevane fekk velje mellom, og dei vala dei gjorde (Vagle \& Evensen, 2005). Prosjektet presenterer derfor ein detaljert analyse av sjanger og tematikk knytt til dei ulike oppgåvene frå dei aktuelle åra.

Ei meir omfattande undersøking av oppgåveformuleringane historisk sett finn vi i Bjarne Øygardens studie frå 2001, der han drøftar sjangeraspektet i skriveoppgåvene frå 1962 til 1999 i lys av dei aktuelle læreplanane (Øygarden, 2001). Han konkluderer med at det fagsynet ein finn i læreplanen, ofte blir forsterka gjennom eksamensoppgåvene, men finn også eksempel på at eksamensoppgåvene ikkje følger opp endring i fagsyn gjennom oppgåveformuleringane. Øygarden peikar på at dette kan skape eit dilemma for lærarane i skulen.

Audhild Norendal har studert danningsperspektivet i eksamensoppgåvene frå 2000 til 2015 (Norendal, 2016). Ho finn at oppgåvene er uttrykk for ei utvikling prega av mindre valfridom og sterkare vektlegging av norskfagleg innhald. Ho peikar på at dette er ei endring frå vektlegging av materielle danningsaspekt, der ein ser innhaldet som vesentleg for danning, mot formale danningsaspekt, der ein legg vekt på at det subjektive må ha rom for å utfalde seg for å oppnå danning. Når Norendal relaterer dette til danningssynet $\mathrm{i}$ læreplanane, ser ho at utviklinga der går i motsett retning.

Alle desse studiane er interessante i seg sjølv. Det som likevel skil arbeidet mitt frå desse, er at eg ikkje primært undersøker samanhengen mellom læreplanane og oppgåvene i dei aktuelle prøvene. Mitt fokus er å undersøke det handlingsrommet oppgåvene gjev svake elevar. Eg ser dessutan heile 
perioden under eitt og har ikkje bare vore interessert i langsvarsoppgåvene. I store delar av materialet finn vi oppgåvesett som markerer eit klart skilje mellom oppgåver som måler leseforståing hos elevane, og reine skriveoppgåver. Eg vil sjå på utviklingstrekk i begge desse oppgåvetypane.

\section{Leseforståingsoppgåver i avgangsprøva}

Leseforståingsoppgåvene presenterer ein tekst før ein stiller ulike typar spørsmål til teksten. Det er interessant å sjå nærare på dei tekstane ein har valt ut for dette føremålet. Det mest vesentlege skiljet går mellom det ein kan kalle tilpassa sakprosa og omplasserte tekstar.

\section{Tilpassa og omplassert sakprosa}

Tilpassa sakprosa er som namnet seier tekstar som er særleg laga for dette føremålet og derfor særleg tilpassa til elevgruppa anten det gjeld språkleg framstilling eller innhald. Før M74 var grunnskulen plandelt. Plandelinga hadde tre definerte nivå, der plan 3 var det fagleg mest krevjande. Det finst derfor også tre ulike sett med eksamensoppgåver. Frå 1967 til 1975 hadde dei tilpassa sakprosatekstane for dei tre ulike planane desse temaa:

\begin{tabular}{|l|l|l|l|}
\hline År & Plan 1 & Plan 2 & Plan 3 \\
\hline 1967 & Myllarguten & Ungdom om idrett & Råd til tenåringar \\
\hline 1968 & $\begin{array}{l}\text { Segn om då domkyrkja i } \\
\text { Trondheim blei bygd }\end{array}$ & $\begin{array}{l}\text { Segn om ein mann som møtte } \\
\text { Haugfolket }\end{array}$ & Norske folkeviser \\
\hline 1969 & Oscar Mathisen & Ulukke med luftballong & Norsk natur i fare \\
\hline 1970 & Utplassering i arbeidslivet & Eit år på folkehøgskole & Kongens nei i 1945 \\
\hline 1971 & Robinson Crusoe & $\begin{array}{l}\text { Redningsaksjon for } \\
\text { trekkfugler }\end{array}$ & Vatnets tydning \\
\hline 1972 & Nødhamn i Finnmark & Ra (Thor Heyerdal) & Fiskerinæringa \\
\hline 1973 & 12-åring sakna i fjellet & $\begin{array}{l}\text { Norsk Selskab til Skibbrudnes } \\
\text { Redning }\end{array}$ & $\begin{array}{l}\text { Norsk Selskab til } \\
\text { Skibbrudnes Redning }\end{array}$ \\
\hline 1974 & $\begin{array}{l}\text { Fridtjof Nansens } \\
\text { nordpolekspedisjon }\end{array}$ & Flyhavari på Fornebu & $\begin{array}{l}\text { Utfordringar med } \\
\text { innføring av fjernsyn i } \\
\text { Noreg }\end{array}$ \\
\hline
\end{tabular}




\begin{tabular}{|l|l|l|l|}
\hline 1975 & Hund som redda ein familie & Naturkatastrofar i Noreg & $\begin{array}{l}\text { Framandarbeidarar i } \\
\text { Noreg }\end{array}$ \\
\hline
\end{tabular}

Tabell 2: Tematisk oversikt over oppgåvene 1967-1975

Tematisk ser vi mange tekstar som handlar om norske heltar og dramatiske hendingar frå verkelegheita (men også med mytiske innslag). Slike tekstar er svært vanlege for både plan 1 og plan 2, men vi finn òg nokre eksempel på tekstar som er relaterte til ungdomstida. I tekstane som er tenkte til dei flinkaste elevane, finn vi ikkje reine helteforteljingar, men fleire tekstar som er relaterte til utviklinga av det norske samfunnet, som til dømes nærings- og medieutvikling.

Drama- og helteframstillingane har klare sakprosatrekk som etablerer ein kontrakt med lesaren om at hendingane verkeleg har funne stad, men framstillingsmåten har også fiksjonstrekk. Særleg er det vanleg at ein nyttar forteljingsforma framfor ei meir klassifiserande, argumenterande og begrepsorientert framstilling. Vi les om Myllarguten frå han blei fødd i Sauherad i 1801 til han heldt konsert saman med Ole Bull i Kristiania 48 år seinare. Her når forteljinga sitt klimaks i den siste setninga: «Og etter den siste slåtten var det som om applausen ingen ende ville ta» (avgangsprøva for 1967).

Dei dramatiske forteljingane frå verkelegheita blir også farga av ei tydeleg forteljarstemme som sørgjer for at spenninga held seg. I ein tekst frå 1975 som handlar om ulike naturkatastrofar, kan vi lese:

Den største ulykka skjedde i 1936 på same staden som den i 1905. Igjen var det Ramnefjellet som var årsaka til katastrofen. Det hadde aldri halde seg heilt roleg etter det første storraset. Stadig gjekk det små steinsprang. Folk i Bødal og Nesdal som hadde rydda gardane på ny, gjekk i stadig frykt (avgangsprøva for 1975). 
Det er ingen tvil om at framstillinga held seg til historiske fakta, men den dramatiske oppbygginga og tankereferata gjer at det minner om ei fiksjonsforteljing.

På mange måtar kan dette verke som ei litt gammaldags framstillingsform, men det å nytte fiksjonstrekk i sakprosa er eit velkjent verkemiddel også i dagens didaktiske tekstar. Særleg finn ein slike fiksjonsinnslag i læreboktekstar (Løvland \& Tønnessen, 1997; Løvland, 2018).

Tekstane som er laga for elevar på plan 3, handlar som nemnt om andre tema. Mange av dei er også prega av forteljingsforma og ein personleg tone, men utover på 70-talet får framstillinga ei meir reindyrka sakprosaform slik som dette utdraget frå avgangsprøva for 1975:

I Norge arbeider omtrent 20 ooo utenlandske statsborgere. Mange av dem kommer fra de nordiske land eller fra andre vestlige land med høy levestandard, men omtrent 6000 har statsborgerskap i land i Sør-Europa, Asia, Afrika eller Mellom-Amerika. Det er disse siste vi gjerne kaller fremmedarbeidere. Mer enn 2/3 av alle utenlandske statsborgere i Norge er menn (avgangsprøva for 1975).

Den tilpassa sakprosaen er altså tydeleg laga for føremålet og for målgruppa. Tekstane er ganske korte, dei har tema som ein anten ventar vil fenge aldersgruppa, slik som dei dramatiske forteljingane, helteforteljingane og tekstane som er ungdomsrelaterte, eller tema som er viktige i eit dannings-perspektiv, slik som tekstar som fokuserer på det norske. Vi finn dessutan ei tydeleg tilpassing til nivå hos elevane gjennom å tilby elevane på nivå 3 tekstar med ein tydelegare samfunnsprofil og sakprosa med færre fiksjonstrekk. 
Tidleg på 8o-talet blir det endringar i tekstane elevane skal lese. Frå 1981 er det slutt på dei tilpassa tekstane (med unntak av teksten frå 1983, som representerer ein mellomting), og elevane møter nå tekstar som er skrivne av namngjevne forfattarar, slik dette oversynet viser:

\begin{tabular}{|l|l|l|}
\hline År & Forfatter & Tittel/tema \\
\hline 1981 & Sissel Benneche Osvold & $\begin{array}{l}\text { «Tredje innbytter» (fiksjonstekst om ein } \\
\text { ung gut) }\end{array}$ \\
\hline 1982 & Finn Carling & $\begin{array}{l}\text { «Et møte» (utdrag frå dokumentarroman } \\
\text { om Vest-Afrika) }\end{array}$ \\
\hline 1983 & Mari & $\begin{array}{l}\text { «Kjære leser» (truleg fiktivt brev og stil frå } \\
\text { ung jente) }\end{array}$ \\
\hline 1984 & Kåre Holt & $\begin{array}{l}\text { «Kappløpet» (utdrag frå dokumentarroman } \\
\text { om Amundsens polarekspedisjon) }\end{array}$ \\
\hline 1985 & Wenche Dager & $\begin{array}{l}\text { «Ensom: Samtale med ei gammal kvinne» } \\
\text { (fiksjonstekst) }\end{array}$ \\
\hline 1986 & Torborg Nedreaas & $\begin{array}{l}\text { Utdrag frå Musikk fra en blå brønn (roman } \\
\text { om jente i puberteten) }\end{array}$ \\
\hline 1987 & Lasse Evensen & $\begin{array}{l}\text { «Kl 00.30 - natt til søndag» (reportasje om } \\
\text { trafikkulykke, Dagbladet) }\end{array}$ \\
\hline 1988 & Leif Isaksen & $\begin{array}{l}\text { «Hu Petra og 'n August» (essayistisk tekst } \\
\text { om tegneserien Stomperud) }\end{array}$ \\
\hline
\end{tabular}

Tabell 3: Oversikt over tekstar skrivne av ulike forfattarar 1981-1988

Teksttypen er oftast litterær sakprosa eller fiksjonslitteratur, men i 1987 presenterte ein for første gong ein faksimile av ein reell avistekst for elevane. Bruk av tekstar som har ein oppgitt forfattar, styrker det autentiske preget denne oppgåvetypen får, men mogelegheita for å tilpasse teksten til målgruppa blir mindre. Ei slik målgruppetilpassing ser vi likevel i val av tema sidan fleire av tekstane (dei frå 81, 83, 86 og 87) handlar om ungdom. Teksttypen skil seg også frå den tilpassa sakprosaen ved å fokusere på kjensler og psykologi framfor kunnskap i langt sterkare grad. Det ser vi mellom anna i teksten frå 1981, der Sissel Benneche Osvold skildrar ein far som ser korleis sonen prøver å vere ein del av laget sjølv om han bare er tredje innbytar og ikkje får spele. 


\section{Spørsmål til tekstane}

I heile perioden frå 1967 til 2000 har ein presentert ein eller fleire kortare tekstar for elevane som det er knytt konkrete spørsmål til. (Frå 2000 og fram til i dag får elevane eit førebuingshefte som gjer at leseoppgåvene blir meir integrerte i skrivedelen - meir om dette under overskrifta «Skriveoppgåver i avgangsprøva».) Målet med spørsmåla og korleis dei er tilpassa ulike føresetnader hos elevane, varierer. I den plandelte perioden var nivådelinga tydeleg. I oppgåvene til alle tre nivåa finn vi spørsmål som krev at elevane finn informasjon i teksten, men progresjonen er tydeleg. Spørsmåla til elevane på nivå 1 og 2 er ofte tydeleg relaterte til informasjon i teksten med mange enkle kva- og kor-spørsmål, medan elevane i større grad må tolke tekstinformasjonen sjølv på nivå 3, slik desse eksempla frå 1973 viser:

Plan 1: «Hvor skulle Steinar da han la ut på turen?»

Plan 2: «I teksten finner du bl.a. årstallene 1891, 1893, 1937, 1945. Hva skjedde disse årene?»

Plan 3: «Kvifor fekk bergingsdådane i 1893 så mykje å seie for Redningsselskapet?»

Ein annan forskjell er at elevane på nivå 1 ofte blir bedne om å uttrykke si subjektive meining knytt til normative spørsmål som «Mener du det var riktig av foreldrene å sende Steinar ut på denne turen?». Slike spørsmål finn ein ikkje (så ofte) på nivå 2 og 3, men her skal elevane i staden forklare 4-5 ord og uttrykk som er bruka i teksten (til dømes «havsnød», «bragd» og «tilskott frå staten» på nivå 2, og «bragd», «installere», «å skipe eit selskap» på nivå 3). Desse forskjellane kan tyde på at ein tenker at elevane på det lågaste nivået har bruk for å kunne lese tekstar som grunnlag for vurderingar i eige liv,
A. Løvland
$14 / 36$
Sakprosa.no 
medan elevane på dei øvste nivåa i større grad har bruk for å kunne lese for å få tilgang til ny kunnskap.

Ein liknande tankegang som den ein kan lese ut av dei plandelte oppgåvene, ligg truleg bak spørsmåla vi finn i dagens nasjonale prøver i lesing, som Utdanningsdirektoratet står bak. Her finn vi denne skildringa av oppgåvene og tekstane:

Oppgåvene og tekstane har ulik vanskegrad. På den måten vil elevar som presterer svakt, klare noko, mens elevar som presterer godt, vil få oppgåver dei synest er utfordrande. Ulike tekstar krev ulike lesemåtar. Enkelte gonger må eleven finne svaret slik det står i teksten. Andre gonger må eleven sjølv tolke, reflektere eller gjere vurderingar, og nokre av dei opne oppgåvene krev òg skriftlege grunngivingar (Utdanningsdirektoratet, 2017).

Kva skjedde så med spørsmåla då plandelinga tok slutt og tekstane endra karakter frå tilpassa sakprosa til omplasserte tekstar? I dei fyrste åra var resultatet av omorganiseringa stort sett at kvart oppgåvesett hadde med ulike spørsmålstypar omtrent slik vi kjenner frå dagens leseprøver. Ein gjekk altså frå eit system der tilpassinga var styrt ovanfrå slik at dei fleste elevane kunne meistre store delar av oppgåvesettet, til eit system der det var oppgåver på alle nivå i same sett. Då vil differensieringa vise seg i etterkant av prøva.

Men denne ordninga fekk ein brå slutt. I 1989 blei dei første eksamensoppgåvene som bygde på den nye læreplanen frå 1987, presenterte. Oppgåvene elevane skulle svare på, blei radikalt endra frå det eine året til det neste. Som ein illustrasjon vil eg presentere leseoppgåvene frå 1988 og 1990.

Oppgåvesettet frå 1988 har teikneserien Stomperud som tema. På framsida finn vi ei teikning av Stomperud og Petra, og leseteksten har tittelen « $\mathrm{Hu}$ 
Petra og 'n August». På framsida av oppgåvesettet frå 1990 finn vi ei teikning av Henrik Ibsen, og teksten elevane skal lese, er henta frå Et dukkehjem. Overgangen frå Stomperud til Ibsen kan lesast metaforisk som ei radikal endring av vanskegrad i denne delen av oppgåvesettet.

\begin{tabular}{|c|c|}
\hline & Tekst: «Hu Petra og 'n August» (av Leif Isaksen) 1988 \\
\hline $\begin{array}{l}\text { Spørsmål der lesaren kan hente } \\
\text { informasjon direkte i teksten }\end{array}$ & $\begin{array}{l}\text { - Hvilke to hovedpersoner finner du i teksten? } \\
\text { - } \quad \text { Hvor i Norge kommer disse personene fra? } \\
\text { - } \quad \text { Hvordan beskrives Petra av } 91 \text { Stomperud? } \\
\text { - } \quad \text { Petra sammenlignes med et kjent maleri. Hvilket? } \\
\text { Et bilde som dette [vedlagt] finner du ofte i ukeblader o.l. } \\
\text { Sammenlign dette bildet med tegningen av Petra på } \\
\text { Stomperuds fang (forsiden). Hvilke likheter og ulikheter } \\
\text { finner du? }\end{array}$ \\
\hline $\begin{array}{l}\text { Spørsmål som krev at lesaren } \\
\text { tolkar informasjonen i teksten }\end{array}$ & $\begin{array}{l}\text { - Hva heter Stomperuds verste rival? Gi en kort karakteristikk } \\
\text { av ham. } \\
\text { - Hvilke menneskelige egenskaper har Stomperud? }\end{array}$ \\
\hline $\begin{array}{l}\text { Spørsmål som krev } \\
\text { sjangerkunnskap }\end{array}$ & \\
\hline $\begin{array}{l}\text { Spørsmål som ber om } \\
\text { informasjon som ikkje finst i } \\
\text { teksten }\end{array}$ & $\begin{array}{l}\text { Velg en tegneseriefigur du kjenner. Hvilke menneskelige } \\
\text { egenskaper har han/hun? }\end{array}$ \\
\hline $\begin{array}{l}\text { Spørsmål der lesaren skal } \\
\text { forklare ord i teksten }\end{array}$ & $\begin{array}{l}\text { - Finn synonymer eller forklar disse ordene/uttrykkene som er } \\
\text { uthevet i teksten: førstegangstjeneste, troskyldige, falt } \\
\text { pladask, rivaler, slu, husbanklån. }\end{array}$ \\
\hline
\end{tabular}




\begin{tabular}{|c|c|}
\hline & Tekst: Utdrag frå Et dukkehjem (Henrik Ibsen) 1990 \\
\hline $\begin{array}{l}\text { Spørsmål der lesaren kan hente } \\
\text { informasjon direkte i teksten }\end{array}$ & \\
\hline $\begin{array}{l}\text { Spørsmål som krev at lesaren } \\
\text { tolkar informasjonen i teksten }\end{array}$ & $\begin{array}{l}\text { - Hvilken tid på året foregår handlinga? } \\
\text { - Hvilket sosialt miljø tilhører Nora og Helmer? Begrunn } \\
\text { - Gi personskildringer av Nora og Helmer slik du møter dem i } \\
\text { - } \quad \text { Hette utdraget. } \\
\text { - Hvordan er forholdet mellom Nora og Helmer? }\end{array}$ \\
\hline $\begin{array}{l}\text { Spørsmål som krev } \\
\text { sjangerkunnskap }\end{array}$ & $\begin{array}{l}\text { - Skuespill, dikt og noveller skiller seg fra hverandre blant } \\
\text { annet ved måten de er satt opp på (utseendet). Hvordan kan } \\
\text { du se at «Et dukkehjem» er et skuespill? } \\
\text { - Er utdraget henta fra begynnelsen, midten eller slutten av } \\
\text { skuespillet? Forklar hvordan du kom fram til svaret. }\end{array}$ \\
\hline $\begin{array}{l}\text { Spørsmål som ber om } \\
\text { informasjon som ikkje finst i } \\
\text { teksten }\end{array}$ & $\begin{array}{l}\text { - Nevn andre skuespill eller dikt som Henrik Ibsen har skrevet. } \\
\text { - Hvilke andre forfattere kjenner du til fra siste halvdel av } \\
\text { 1880-tallet? } \\
\text { - Nevn titler på noe de har skrevet, eller fortell om noe de var } \\
\text { opptatt av. }\end{array}$ \\
\hline $\begin{array}{l}\text { Spørsmål der lesaren skal } \\
\text { forklare ord i teksten }\end{array}$ & $\begin{array}{l}\text { Plukk ut fem av de følgende orda og forklar hva de betyr: } \\
\text { replikk, scene, instruktør, rolle, kulisse, scenograf, akt, } \\
\text { komedie, tragedie, rampelys. }\end{array}$ \\
\hline
\end{tabular}

Tabell 4: Spørsmål knytte til ein tekst i oppgåvesettet frå 1988 og 1990

Som vi ser, er det mange fleire spørsmål som krev at lesaren tolkar teksten i 1990, enn det som var tilfellet i 1988. Det er også typisk at oppgåvene frå 1989 og framover legg vekt på at elevane har omfattande sjangerkunnskap og annan kunnskap om forfattarar og litteratur som ein ikkje kan finne i teksten. 
Som eg tidlegare har vore inne på, har det å teste ordkunnskap knytt til lesetekstar vore ei gjennomgåande oppgåvetype frå 6o-talet og fram til 1991. Det er likevel interessant å merke seg at orda elevane skal forklare, har endra karakter i dette tidsrommet. I plandelingstida kan ein som nemnt sjå klare nivåforskjellar i ordutvalet til dei ulike planane. Etter denne perioden finn eg ikkje ei liknande tilpassing til nivå i dei utvalde orda; dei representerer meir ein middelveg. Men også i dette høvet markerte 1987 eit tydeleg brot med tradisjonen. Fram til 1989 var orda elevane skulle forklare, allmenne ord som dei ville ha nytte av å kunne i dagleglivet eller for å lese andre tekstar som kan bidra til allmennkunnskap. I oppgåveheftet i 1988 finn vi desse orda: «førstegangstjeneste», «falt pladask», «slu», «troskyldig», «rivaler» og «husbanklån». Her kan ein lese inn ein litt traust norsk kontekst knytt til livet som ungdom fram til ein er etablert i eige hus. Orda står i sterk kontrast til desse orda frå 1990, som har ei mykje sterkare litterær tilknyting: «replikk», «scene», «instruktør», «rolle», «kulisse», «scenograf», «akt», «komedie», «tragedie» og «rampelys».

Dei nemnde endringane som fann stad på slutten av 80-talet, markerer eit tydeleg skilje i synet på norskfaget. Der faget tidlegare hadde teke på seg ansvaret for å ruste elevane i generell lesedugleik, blei norskfaget meir og meir eit fag med eit eige litterært eller språkleg innhald som elevane skulle prøvast i. Dette er ei interessant vending sett med dagens briller. Etter det som har blitt omtalt som PISA-sjokket i 2001, der norske elevar gjorde det relativt dårleg i den første internasjonale lesetesten, har ein igjen retta fokuset mot lesing som ei grunnleggande ferdigheit, men nå er ansvaret fordelt mellom alle faga i skulen (Utdanningsdirektoratet, 2016, LKo6). Det er rimeleg å tru at det brå skiftet i tenkinga om kva norskfaget skulle vere, som ein finn på åttitalet, måtte etterlate seg eit tomrom som ikkje blei fylt før i 2006. Eit anna perspektiv som eg vil kome tilbake til, er om ein også kan lese denne vendinga som ei endring som påførte dei svake elevane eit ansvar for eiga utvikling som kanskje har vore for stort. 


\section{Skriveoppgåver i avgangsprøva}

Dei fleste vaksne som hugsar tilbake til den dagen dei var oppe til eksamen i norsk i grunnskulen, tenker nok mest på at dei skreiv «norsk stil». Sjølv om alle oppgåvesetta frå 1967 og fram til i dag også har eit tydeleg leseperspektiv, er nok kjensla av at dette er ei prøve i skriving, sterk.

\section{Skriving av funksjonell sakprosa}

Det er eit gjennomgåande trekk at alle prøvene gjev elevane ei form for valfridom. Dei kan velje ei av fleire mogelege skriveoppgåver. Men oppgåvesetta i tidsrommet har også lenge hatt ei anna skriveoppgåve som oftast var obligatorisk. Frå 1967 og fram til 1985 var skriving av funksjonell sakprosa eit vanleg innslag, slik denne oversikta viser:

\begin{tabular}{|l|l|}
\hline & \\
\hline 1967 & $\begin{array}{l}\text { Plan 1: Skriv brev til fjellstove } \\
\text { Plan 2: Skriv brev til fjellstove }\end{array}$ \\
\hline 1968 & $\begin{array}{l}\text { Plan 1: Skriv jobbsøknad } \\
\text { Plan 2: Skriv jobbsøknad }\end{array}$ \\
\hline 1969 & $\begin{array}{l}\text { Plan 1: Skriv etter katalog } \\
\text { Plan 2: Skriv etter katalog og skriv bestillingsbrev }\end{array}$ \\
\hline 1970 & $\begin{array}{l}\text { Plan 1: Skriv jobbsøknad } \\
\text { Plan 2: Skriv brev til folkehøgskule }\end{array}$ \\
\hline 1971 & $\begin{array}{l}\text { Plan 1: Skriv brev til symjeklubb } \\
\text { Plan 2: Skriv etter tidsskrift og fyll ut postgiroblankett }\end{array}$ \\
\hline 1972 & $\begin{array}{l}\text { Plan 1: Skriv etter avisartikkel } \\
\text { Plan 2: Skriv brev til museum }\end{array}$ \\
\hline 1973 & $\begin{array}{l}\text { Plan 1: Skriv brev til orienteringsklubb } \\
\text { Plan 2: Skriv brev til FN-sambandet }\end{array}$ \\
\hline 1974 & $\begin{array}{l}\text { Plan 1: Skriv brev til hytteutleigar } \\
\text { Plan 2: Skriv brev til Oslo lufthavn }\end{array}$ \\
\hline 1975 & $\begin{array}{l}\text { Plan 1: Skriv brev til yrkesskule } \\
\text { Plan 2: Skriv brev til hytteutleigar }\end{array}$ \\
\hline 1976 & [Manglar i materialet] \\
\hline 1977 & Skriv søknad om sommarjobb \\
\hline 1978 & Skriv svar på annonse \\
\hline 1979 & [Ingen] \\
\hline 1980 & Skriv jobbsøknad \\
\hline
\end{tabular}




\begin{tabular}{|l|l|}
\hline 1981 & Valfri: Skriv til Svenska turistföreningen \\
\hline 1982 & Valfri: Skriv jobbsøknad \\
\hline 1983 & Valfri: Svar på annonse \\
\hline 1984 & Valfri: Svar på annonse \\
\hline 1985 & Svar på annonse \\
\hline
\end{tabular}

Tabell 5: Skriving av funksjonell sakprosa 1967-1985

Det er interessant å merke seg at slik funksjonell sakprosa i plandelingsperioden var obligatorisk for plan 1 og 2, medan oppgåvetypen ikkje fanst i plan 3-settet. Dette kan ein forstå som at ei yrkesretta skriveoppgåve ikkje var naudsynt for dei som skulle studere vidare, slik planen nok ofte var for dei mest evnerike elevane. Etter at plandelinga tok slutt, blei denne oppgåveforma dels obligatorisk, dels valfri, før ho forsvann i 1986.

\section{Innføring av inspirasjonstekstar}

Stilskrivinga eller langsvarsoppgåvene som mange hugsar som hovudaktiviteten på eksamensdagen, har også gått gjennom ei utvikling som er knytt til ulike sider ved oppgåvene. Det fyrste eg vil kommentere, er synet på kor elevane skal finne stoff til det dei skal skrive om. Den tradisjonelle forma for stilskriving gjekk ut på at elevane skulle hente stoffet frå eige hovud, anten det var snakk om rein dikting eller meir sakprega argumentasjon. Slike oppgåver finn vi frå 1967 til 1987, men frå 1989 innførte ein oppgåver som på ulikt vis presenterte elevane for tekstar som skulle inspirere og gje dei stoff til skrivinga. Denne endringa er samanfallande med at den prosessorienterte skrivepedagogikken får innpass i Noreg. I boka Skriving som prosess: Innforing og praktiske ideer i prosessorientert skriving skriv Gro Flaten og Anne-Karin Korsvoll i 1989: 
Til idefasen regner vi alle aktiviteter som kan stimulere og forberede elevene til å skrive. Dette er en avgjørende fase i skriveprosessen fordi den setter hele prosessen i gang. Mye tyder på at vi har viet altfor liten oppmerksomhet til denne delen av skriveprosessen. En undersøkelse viser at den amerikanske high schoolstudenten bruker i gjennomsnitt 3 minutter til dette forberedende stadiet, og det er vårt inntrykk at heller ikke våre elever vier denne fasen noe særlig oppmerksomhet (Flaten \& Korsvoll, 1989, s. 40).

Denne overtydinga om at elevane treng inspirasjon i idefasen, har seinare aldri blitt fortrengd frå avgangsprøva i norsk. Det vil derfor vere interessant å sjå nærare på kva form inspirasjonstekstane har hatt gjennom desse nesten 30 åra.

Det er likevel ikkje heilt sant at ein ikkje hadde presentert elevane for tekstar til inspirasjon i dei tidlegare oppgåvesetta. Gjennom alle desse åra har ein mellom alle andre slags oppgåver ofte hatt med dikt som skal lesast og kommenterast på ulike måtar. I 1967 fekk plan 3-elevane lese Einar Skjæraasens dikt «Du ska itte trø i graset» og svare på oppgåva «Kva tankar og kjensler får du når du les dette diktet?», medan elevane i 1987 skulle skrive eit avisinnlegg med utgangspunkt i Einar Øklands dikt «Borte i natta». Men gjennomgåande for oppgåvene før 1988 var at det bare var lyrikk som kunne gje denne forma for inspirasjon, og at ein i tillegg hadde mange andre oppgåver for dei elevane som ville hente inspirasjon frå sitt eige hovud. Det er også interessant å merke seg at det bare var plan 3-elevane som fekk mogelegheita til å løyse denne typen oppgåver, noko som kan tyde på at ein såg på dette som avansert og ikkje noko som ville vere til hjelp for dei svakaste elevane.
A. Løvland
$21 / 36$
Sakprosa.no 
Sjølv om ein altså har innført inspirasjonstekstar som ein obligatorisk del av oppgåvene, er sambandet mellom slike tekstar og dei skriveoppgåvene elevane får, svært varierte. Det er med andre ord mange måtar å få og bruke inspirasjonen på. Dei tidlege lyrikkoppgåvene representerer eit tett samband mellom tekst og oppgåveformuleringa som gjev elevane sterk styring, medan det finst tekst-oppgåve-samband som gjev elevane mykje større valfridom, og også samband som kan vere krevjande å oppdage. Valfridom finn ein til dømes i oppgåvesettet frå 1989, der mange av oppgåvene er merka med tekstar som: «Hvis du vil, kan du lese sidene merket B 1 for å få ideer til teksten din», medan oppgåvesettet for 1998 har døme på inspirasjonstekstar der det kan vere vanskeleg å oppdage koplinga mellom teksten og oppgåveformuleringa. I ei av desse oppgåvene blir elevane presenterte for oppgåveformuleringa «Skriv en tekst der temaet er løgn» og eit abstrakt kunstverk av Fernand Léger. Tolkingsrommet i er stort, men det er vanskeleg å finne relasjonen mellom det og den presise bestillinga.

\section{Innføring av førebuingsdel}

Frå 2000 og fram til i dag har eksamen i norsk hatt ein førebuingsdel. Elevane får nå eit teksthefte på førehand som gjer det mogeleg for dei å bu seg til eksamensdagen. Heftet gjer det mogeleg å presentere elevane for fleire og meir omfattande tekstar som også gjer til at dei kan få meir ut av inspirasjonstekstane. Praksisen rundt tekstheftet og relasjonen mellom tekstane og skriveoppgåvene er likevel variert. Ein gjennomgang viser tre typiske tekstpraksisar som følger etter kvarandre i tid. Tida frå 2000 til 2007 er første periode, ${ }^{2}$ åra frå 2009 til og med 2013 utgjer den neste, og tida etter 2013 er ein tredje periode som kanskje vil halde fram i fleire år framover.

2 Oppgåvesettet for 2008 står i ei særstilling fordi det dette eine året blei arrangert ein felles eksamensdag i hovud- og sidemål.
A. Løvland
$22 / 36$
Sakprosa.no 


\section{Svak styring}

Den første perioden er prega av at elevane blir lite styrte i skrivesituasjonen. I det meste av perioden har ein eit skilje mellom kortsvarsoppgåver som er knytte til tekstheftet, og langsvarsoppgåver som presenterer nye tekstar for elevane. Kortsvarsoppgåvene representerer ein mellomting mellom lese- og skriveoppgåver. Her skal ein ofte finne informasjon av ulikt slag i tekstane, men også skrive sjølvstendig om relaterte tema. Det er stor valfridom i desse oppgåvene; ofte skal elevane svare på ei obligatorisk oppgåve og så velje éi av 5-7 oppgåver.

Sidan valfridomen i kortsvarsoppgåvene er stor og mange av oppgåvene representerer eit laust samband mellom tekst og skriveoppgåve, kan elevane i stor grad velje om dei vil bruke dei mogelegheitene inspirasjons-tekstane gjev, eller skrive meir fritt ut frå eigen fantasi og eigne erfaringar. Det same gjeld i høg grad langsvarsoppgåvene. Sjølv om det er eit vanleg trekk i perioden å knyte ei konkret oppgåve til ein utvald tekst, er teksten i liten grad styrande for kva eleven kan skrive om. Det kan vere at elevane blir bedne om å skrive om eit bilete eller eit dikt, men bileta i oppgåvene fungerer også ofte bare som ein illustrasjon.

Mange av langsvarsoppgåvene er så laust knyte til inspirasjonsteksten at forskjellen mellom desse oppgåvene og oppgåvene frå 60- og 70-talet, som ikkje hadde slike tekstar, er liten - slik denne samanstillinga av oppgåver frå 1967 og 2000 viser: 
1967 (plan 1): «Min største idrettsopplevelse»

2000:

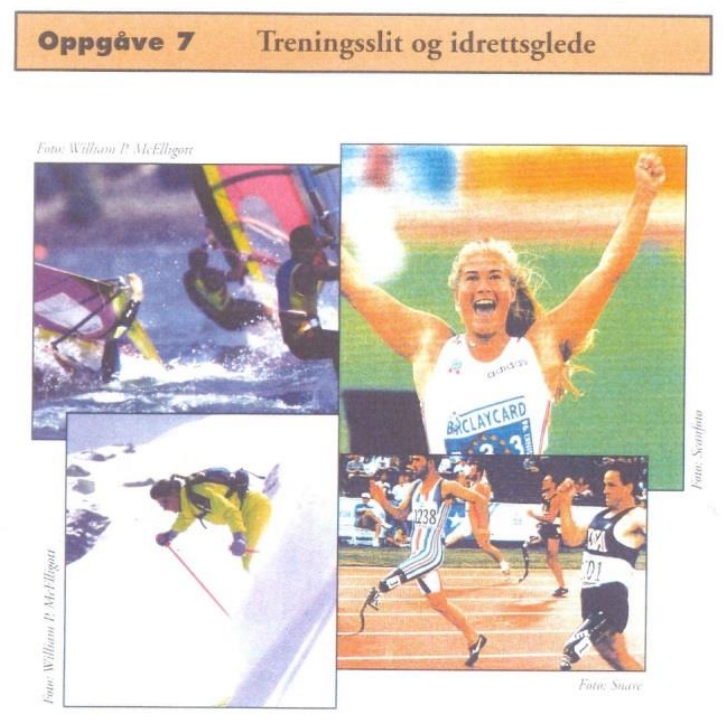

\section{Oppgåve:}

Skriv eit essay eller eit kåseri om ei idrettsgrein som gir deg glede.

Lag ein tittel som passar.

Eller

Lag ein reportasje frå ei idrettshending.

Lag overskrift sjolv.

Figur 1: Samanlikning av oppgåveformulering frå 1967 og 2000

Den manglande styringa og valfridomen når på mange måtar toppen i oppgåvesetta frå 2006 og 2007. I desse åra blei det ikkje laga oppgåver til tekstane i tekstheftet i det hele. I rettleiinga til elevane står det:

Innholdet i heftet er ment å være en kilde til informasjon og inspirasjon når du skal skrive en sakprega tekst med dette temaet [...]. På skrivedag 1 blir det ikke gitt oppgaver. Du skal lage ditt eget skriveprosjekt. Det vil si at du selv avgjør hva du vil skrive om 
ut fra det du finner interessant innenfor temaet (avgangsprøve i grunnskolen 2007, norsk, s. 3).

Denne praksisen blei avvikla etter to år og var på mange måtar sluttpunktet for den opne tilnærminga til skriving i avgangsprøva.

\section{Tydelegare rammer for skrivinga}

Frå 2009 og til og med 2013 skulle elevane bare svare på éi oppgåve som kunne veljast frå eit oppgåvesett. Dette tyder at det ikkje lenger er oppgåver i settet som alle elevane må svare på. Ein vekslar også mellom å skrive sakprega og skjønnlitterær tekst. Elevane blir framleis presenterte for eit teksthefte som har ein tematisk samanheng som er utgangspunktet for oppgåvene. Sjølv om det varierer om oppgåvene er direkte knytte til éin eller fleire tekstar i heftet, er det ikkje lenger opp til eleven korleis han vil bruke inspirasjonen han får frå heftet. Oppgåveformuleringane styrer nå i sterkare grad korleis elevane skal bruke inspirasjonen i den teksten dei skriv, slik vi til dømes ser i desse formuleringane frå 2009:

Oppgåve 2: Humor kan vere ulik mellom: bygd og by, gammal og ung, nord og sør, før og no, gut og jente og mellom ulike miljø. Ta utgangspunkt i éin eller fleire av kontrastane ovanfor. Skriv ein sakprega tekst om kva humoren din blir påverka av, og kva som gjer han ulik humoren til andre. Vel tittel sjølv.

For å skrive denne oppgåva må elevane godta at påstanden som blir presentert innleiingsvis, er rett, og også korleis dette kan vere relevant for eigen humor. Styringa i denne oppgåveformuleringa er sterk, og denne oppgåvetypen viser at den skrivekompetansen elevane treng, nå blir meir avhengig av om han forstår premissane for skrivinga. Desse premissane vil styre korleis han kan bruke tekstheftet som kjelde til å skrive. På mange måtar ser vi nå at 
funksjonen til tekstane ikkje lenger er inspirasjonstekst, men meir ei kjelde til tekstrefleksjon.

Styringa elevane møter i oppgåveformuleringane, er sterkare i oppgåvene som skal munne ut i sakprega tekstar, enn i oppgåvene som skal få elevane til å skrive skjønnlitteratur. Det er likevel interessant å sjå at ein også i desse oppgåvene legg føringar for kva teksten skal handle om, som i denne oppgåva frå 2011: «Skriv ein skjønnlitterær tekst der hovudpersonen opplever korleis det er å ikkje kunne uttrykke meiningane sine. Lag ein passande tittel.» Med det biletet mange av oss har om den frie og individuelt inspirerte skjønnitteraturen, blir ein lett litt overraska over denne forma for «oppdragsskjønnlitteratur» der oppdragsgjevaren styrer tematikken i teksten.

Relasjonen mellom oppgåveformulering og tekstane i førebuingsheftet blir bare sterkare mot slutten av det eg har definert som denne perioden. I oppgåvesettet frå 2013 er alle oppgåvene elevane kan velje mellom, knytte til ein konkret tekst. Elevane får også mange og ganske presise føringar for kva teksten han skal skrive, skal innehalde, slik vi ser i denne oppgåva frå det aktuelle settet:

Oppgåve 5: I Salmonsens konversasjonsleksikon fra 1915 defineres en helt slik: «Ved en Helt forstaar man den, der med ophøjet Energi og Mod sætter sit Liv ind i Kampen for en stor Sag [...] der kommer Menneskeheten til gode.»

Skriv en artikkel der du reflekterer over helter før og nå i lys av denne definisjonen. Bruk minst to kilder i argumentasjonen din. Lag en passende overskrift.

I oppgåvesettet frå 1977 kan elevane velje oppgåva «Et menneske jeg ser opp til». Sjølv om dei to oppgåvene minner mykje om kvarandre når det gjeld 
tematikk, er avstanden stor når det gjeld rammene for kva ein kan skrive. Der den eldste oppgåva krev at eleven kan kome på noko å skrive om og sjølv legge ein plan for korleis han skal skrive teksten, kan eleven i 2013 finne idear i tekstsamlinga, men må samstundes passe på å halde seg til premissene i oppgåveformuleringa.

\section{Oppgåver med klar relasjon til tekstheftet}

Denne vektlegginga av at elevane skal lese tekstane i tekstheftet med eit bestemt siktemål, blir ytterlegare forsterka i den siste perioden. Frå $2014 \mathrm{og}$ fram til 2017 har ein igjen valt å satse på fleire skriveoppgåver samstundes som ein snevrar inn valfridomen ytterlegare. Nå har oppgåvesettet ei eller to obligatoriske oppgåver og ei valfri. Felles for alle oppgåvene er at dei har ei sterk tilknyting til ein eller fleire tekstar i tekstheftet som elevane har hatt høve til å arbeide med på førehand. Oppgåveformuleringane inneheld påstandar om korleis ein som lesar skal forstå den aktuelle teksten, og presise bestillingar til den teksten eleven skal produsere. Dette ser vi til dømes i denne oppgåveformuleringa frå den valfrie delen av 2014-settet:

\section{Oppgåve B3}

Teksten Liket av Tor Jonsson handlar om «bygdedyret»: Eit lokalsamfunn latterleggjer og frys ut ein ung gut fordi han skil seg ut. «Bygdedyret» kan vise seg på mange ulike måtar, som fordommar, rykte, intoleranse, misunning og flokkmentalitet. «Bygdedyret» kan opplevast på sosiale medium, i skolekvardagen, i lokalsamfunnet eller andre stader.

Skriv ein tekst som skal brukast i samband med ein haldningskampanje på skolen din. Bodskapen skal vere at vi må stå saman i kampen mot «bygdedyret». Teksten din skal skape 
engasjement hos tilhøyraren eller lesaren. Lag ei overskrift som passar til bodskapen din.

Her făr eleven vite korleis ein bør lese Tor Jonssons tekst, og korleis denne kan vere relevant i dag. Han får også konkret informasjon om kva kommunikasjonssituasjon teksten han sjølv skal skrive, skal gå inn i, kva bodskapen skal vere, og kva verknad teksten skal ha på lesaren. Desse strenge skriverammene kan kanskje gje ein flink skrivar som likar klare rammer, inspirasjon til å skrive ein god tekst, men for ein svakare skrivar og også for ein kreativ skrivar kan dette truleg opplevast som ei tvangstrøye.

\section{Skrivehandlingar i oppgåvesetta}

Dei ulike skrivehandlingane som er skildra i Skrivehjulet (Skrivesenteret, 2013), går igjen i dei femti årgangane av avgangsprøva. Elevane har gjennom heile perioden fått oppgåver der dei kan førestelle seg noko, beskrive, utforske, reflektere, samhandle og overtyde. Det er likevel tydeleg at valfridomen, presisjonsnivået og kompleksiteten i dei skrivehandlingane elevane skal utføre, har variert gjennom desse femti åra. Ein hovudforskjell er at i eldre oppgåvesett kan ein sjå at oppgåvesettet som heilskap tilbyr oppgåver som krev ulike skrivehandlingar. Dei ulike handlingane var gjerne knytte til ein sjanger eller eit produkt, men oppgåvesetta var gjerne komponerte slik at elevane til dømes kunne velje mellom å dikte opp noko, å reflektere over eigne erfaringar eller å argumentere for ulike synspunkt. I dagens skriveoppgåver er mykje av denne valfridomen borte, og dei skrivehandlingane elevane skal utføre, er meir komplekse. Dette ser vi til dømes i denne obligatoriske oppgåva frå 2016:

Skriv en tekst der du på en vennlig måte henvender deg til en medelev og forklarer hvorfor teateromtalen i VG kan være vanskelig å forstå. Gi tips om hvordan han eller hun best kan
A. Løvland
$28 / 36$
Sakprosa.no 
angripe teksten for å forstå den bedre. Vis kunnskap om lesing og lesestrategier i teksten din.

For å løyse ei slik oppgåve må eleven vise at han kan samhandle med andre elevar, at han kan forklare eit saksforhold, at han kan argumentere og tilrå ein framgangsmåte samtidig som han også viser kunnskap (her er truleg sensorane ei ny mottakargruppe). Dette er ein kompleksitet som vi ikkje tidlegare fann i oppgåvene.

\section{Drøfting av avgangsprøva og målsettinga om tilpassing til føresetnadene hos elevane}

I innleiinga presenterte eg ei interesse for å karakterisere samanhengen mellom avgangsprøva i norsk og målsettinga om at norskfaget skal bidra til å utvikle språkkompetanse hos elevane ut frå dei evnene og føresetnadene den enkelte eleven har. Materialet eg har gått gjennom, er omfattande og variert, men eg har likevel sett trekk som gjer det mogeleg å peike på ei utvikling over tid på dette feltet som eg vil presentere under merkelappane tilpassa regulering, tilrettelagd valfridom og krevjande likebehandling.

\section{Tilpassa regulering}

Tilpassa regulering er kjenneteikna av at ein autoritet tek ansvaret for å regulere skulepraksisen og evalueringssystemet på ein måte som skal gjere at den enkelte ikkje blir presentert for oppgåver som «går over hovudet» på ein. Plandelinga av undervisning og også eksamen er eit tydeleg eksempel på eit slikt system, men dette ansvaret er også tydeleg i praksisen med å spesiallage tilpassa sakprosatekstar. Denne praksisen heldt ein fram med også etter at ordninga med plandeling var avslutta. Ein slik praksis viser at ein ser på skule som ein treningsarena der nivå og progresjon skal haldast under oppsyn. Eit formelt nivådelt system verkar fjernt og stigmatiserande i dagens skulesystem.
A. Løvland
$29 / 36$
Sakprosa.no 
Det er opplagt at ei slik tilrettelegging kan bidra til at elevane ikkje får tilstrekkelege utfordringar og at dei også kan bli hengande fast i ein progresjon som ikkje lenger passar for dei. På den andre sida vil mange elevar kunne oppleve meistringskjensle sidan dei oppgåvene dei får, ligg innanfor den næraste utviklingssona.

\section{Tilrettelagd valfridom}

Den evalueringspraksisen eg har kalla tilrettelagd valfridom, er kjenneteikna av at ein ikkje lenger har ein autoritativ nivåtilpassing. Tilrettelegginga går ut på å gje elevane valfridom og handlingsrom til å finne oppgåver som reflekterer nivået og interessene deira. Praksisen reflekterer ein tanke om at det samfunnet elevane skal ut i, stiller ulike krav til norskferdigheiter, og at elevane sjølve må ta ansvaret for å finne fram til det som passar føresetnadene deira best. Praksisen er kjenneteikna av at ein hentar tekstar frå verkeleg samfunnsliv. Elevane skal gjennom differensierte lese- og skriveoppgåver finne det nivået som gjer dei klare for å delta i samfunnet. Problemet med ein slik valfridom er truleg at det samfunnet som skal møte elevane, ikkje veit kva dei eigentleg kan, sidan ein kan løyse relativt enkle oppgåver på ein tilfredsstillande måte. Det er likevel eit system som kan skåne elevane for nederlag dei ikkje treng.

\section{Krevjande likebehandling}

Krevjande likebehandling er ein evalueringspraksis som legg lista høgt gjennom å snevre inn den valfridomen den enkelte elev har i systemet. Dette kan skje ved at ein gjer fleire oppgåver obligatoriske, men også ved at ein formulerer oppgåvene på ein måte som tek bort mogelegheita for å løyse dei på fleire ulike måtar. Det kan vere ulike grunnar til ein slik praksis. Tanken om at ingen skal få ei lettare reise enn andre, kan vere ein av dei, men ein kan også tenke seg ei grunngjeving som seier at oppgåvene etterspør ein norsk- 
fagleg kompetanse elevane vil trenge for å klare seg i dagens utdanningssamfunn. Sidan elevgruppa er like variert som tidlegare, vil eit slikt system nødvendigvis føre med seg at ein del elevar må gå i gang med oppgåver dei ikkje har føresetnader for å meistre.

Ansvaret for tilpassing til føresetnadene hos den enkelte eleven er sentralt i denne inndelinga. I læreplanane blir tilpassinga framstilt som å ligge på systemnivået, men slik evalueringspraksisen har utvikla seg, blir ansvaret meir og meir individuelt. I dagens evalueringspraksis er det dessutan mogeleg å hevde at dei svakaste elevane ikkje lenger har ansvar for å lukkast, men heller eit ansvar for å mislukkast i minst mogeleg grad.

\section{Tankar om samfunnsmessig bakgrunn}

Mange av dei endringane ein kan finne når ein ser historisk på avgangsprøva som tekstform, er klart relaterte til trendar i fagdidaktikken. Undervegs i artikkelen har eg mellom anna peika på samanhengen mellom synet på skriving som prosess og fleire av dei endringane som skjedde på 80- og 90talet. Men det er også freistande å tolke funna frå analysen inn i ein meir generell skule- og kunnskapsdebatt der vinden blæs i retning av reell og retorisk vektlegging av instrumentell kunnskap som eit verkemiddel for auka vekst og velstand. I mange samanhengar ser vi at kunnskap blir sett på som ein redningsplanke, her formulert av rådmannen i Sør-Varanger, som er uroa for utviklinga i landsdelen:

Rådmann Nina Bordi sier at Sør-Varanger er i omstilling og at utdanning er viktigere enn noensinne.

- Kunnskap er den nye oljen. Regional utvikling henger sammen med lokal kompetanse, sier hun.

- Mer innovasjon skaper arbeidsplasser, og gjør at næringslivet kan konkurrere lokalt og nasjonalt. I Tromsø, Bodø og Alta ser vi 
dessuten at studenter ofte blir permanente innbyggere, og den effekten ønsker vi her også, sier Bordi (Hamran, 2017).

Eller som Abelia (NHOs foreining for kunnskaps- og teknologiverksemder) skriv i høyringsinnspelet sitt til årets statsbudsjett:

Abelia mener den viktigste politiske oppgaven framover er å bidra i utviklingen av et kunnskapsbasert, innovativt og globalt konkurransedyktig næringsliv. Dette vil sikre framtidig velferd, sysselsetting og verdiskaping. For å få til dette må vi investere i kunnskap, i barnehage og skole, læring gjennom hele livet og forskning (Abelia, 2017).

Næringslivet har ei ukueleg tru på at kunnskap er eit verkemiddel for vekst. Truleg er det ikkje primært den norskfaglege kompetansen dei tenker på, men det er rimeleg å tenke at også norskfaget treng å legitimere seg med liknande samfunnsnytteargument. Slik blir det å kunne hente ut og bruke informasjon ein viktig kompetanse, medan skriving som eit danningsprosjekt kjem i bakgrunnen.

Norendals studie av danningsperspektivet i eksamensoppgåver frå 2000 til 2015 viser også ei utvikling frå formale i retning av materiale danningsaspekt etter overgangen frå L97 til Kunnskapsløftet. Ho fryktar at denne utviklinga kan føre til at skriveopplæringa endrar seg mot å sjå skriving som måltilpassa funksjonelle handlingar framfor å øve opp det nære blikket og den personlege involveringa i det elevane skriv (Norendal, 2016, s. 15).

I denne artikkelen har det vore viktig å sjå endringane i eit tilpassingsperspektiv. Kva handlingsrom har dei svake elevane innanfor dei oppgåvene dei får, og kven tek ansvaret for at eksamen ikkje skal bli eit nederlagsprosjekt for dei? «Planken» er ein kjend - og kanskje også stigmatiserande - metafor. 
Det er vanskeleg å oppdage redningsplanken for svake elevar i dei nyaste eksamenssetta. På mange måtar verkar det heller som om Utdannings-Noreg ber dei om å «gå planken».

A. Løvland 


\section{Kjelder}

Abelia. (2017). Høringsinnspill for Statsbudsjettet 2018: Finanskomiteen.

Henta frå https://www.abelia.no/politikk/nyheter/statsbudsjettet2018/horinger/horingsinnspill finans/

Flaten, G. \& Korsvoll A.-K. (1989). Skriving som prosess: Innføring og praktiske ideer i prosessorientert skriving. Oslo: Universitetsforlaget.

Forsøksrådet for skoleverket. (1960). Læreplan for forsøk med 9-årig skole. Oslo: Aschehoug.

Hamran, T. (2017, 23. november). Trenger kunnskap - Diskusjon: Hvordan kan Kirkenes møte framtidens kunnskapsbehov? Sør-Varanger Avis, s. 4-5.

Johnsen, E.B. (1997). Oppgavetekst og dannelse: Artiumsstilens emner, formuleringer og forvaltning 1880-1991 (doktorgradsavhandling). Det historisk-filosofiske fakultet, Universitetet i Oslo. (Acta humaniora 6).

Kirke- og undervisningsdepartementet. (1974). Mønsterplan for grunnskolen. Oslo: Aschehoug.

Kirke- og undervisningsdepartementet. (1987). Mønsterplan for grunnskolen. Oslo: Aschehoug.

Kirke-, undervisnings- og forskningsdepartementet. (1996). Læreplanverket for den 10-årige grunnskolen. Oslo: Nasjonalt læremiddelsenter. 
Løvland, A. \& Tønnessen, E.S. (1997). Fiksjon og fakta i lærebøker:

Vurdering av fiksjonsinnslag i seks lærebøker (KULTs skriftserie 76). Oslo:

Norges forskningsråd.

Løvland, A. (2018). Fagbøker for barn. I R.S. Stokke \& E.S. Tønnessen (red.), Møter med barnelitteraturen (s. 219-236). Oslo: Universitetsforlaget.

Norendal, A. (2016). Danningsperspektiver i grunnskolens eksamensoppgaver i norsk. Acta Didactica Norge, 10(3), 1-25, doi: 10.5617/adno.2570

Skjeggestad, H. (2018, 7. mai). Eksamensordningen er gammeldags og utdatert: Skolen skal fornyes, men eksamen skal bestå. Den løsningen står til stryk. Aftenposten. Henta frå https://www.aftenposten.no/meninger/kommentar/i/QlBnm4/Eksamensord ningen-er-gammeldags-og-utdatert--Helene-Skjeggestad

Skrivesenteret. (2013). Skrivehjulet. Henta frå

http://www.skrivesenteret.no/ressurser/skrivehjulet/

Utdanningsdirektoratet. (2011). Internasjonale studier om norsk skole (Temanotat 2011:2). Henta frå

https://www.udir.no/Upload/Rapporter/temanotat/Internasjonale studier om norsk skole temanotat.pdf?epslanguage $=$ no

Utdanningsdirektoratet. (2013). Læreplan i norsk (NOR1-O5). Henta frå https://www.udir.no/klo6/NOR1-05

Utdanningsdirektoratet (2016). Læreplanverket (LKo6). Å forstå grunnleggende ferdigheter. Henta frå https://www.udir.no/laring-ogtrivsel/lareplanverket/a-forsta-grunnleggende-ferdigheter/ 
Utdanningsdirektoratet. (2017). Kva måler nasjonale prøver i lesing? Henta frå https://www.udir.no/eksamen-og-prover/prover/nasjonaleprover/mestringsbeskrivelser-og-hva-provene-maler/kva-maler-lesing/

Vagle, W. \& Evensen, L.S. (2005). Oppgavesettene og elevenes oppgavevalg i KAL-årene. I K.L. Berge mfl. (red.), Ungdommers skrivekompetanse: Norskeksamen som tekst, bd. 1 (s. 161-204). Oslo: Universitetsforlaget.

Øygarden, B. (2001). Kvar vart det av stilen? Om skriftlege sjangrar ved avgangsprøva i grunnskulen 1962 til 1999. I L. Kulbrandstad \& G. Sjølie (red.), På Hamar med norsk: Rapport fra konferansen «Norsk på ungdomstrinnet», del 1 (s. 52-72). Henta frå https://brage.bibsys.no/xmlui/bitstream/handle/11250/133972/rapp11 2001 .pdf? sequence $=1$ \&isAllowed $=\mathrm{y}$ 